\title{
Analysis of Indonesian Export-Import Trade Contaction to Destination Countries
}

\author{
Indria Mayesti, Abd. Halimm, Ardi Afrizal \\ Faculty of Economics and Business, Muhammadiyah Jambi University, Indonesia \\ Correspondence email: ardiafrizal1985@gmail.com, mayestiindria8@gmail.com, abdh0074@gmail.com
}

\begin{abstract}
The objective of this research is to model the growth and contraction in Indonesia's export-import trade against destination countries, where for countrieslike China are in an average import contraction of \$5,649.13 or 0.26\%. Then for Japan, with an average export contraction of $\$ 8,387.62$ or a growth of $5.31 \%$. Furthermore, for Malaysia, where the import contraction amounted to \$6,391.08 or with an average contraction of \$291.51. Then for Singapore it experienced a contraction of imports of $\$ 3,489.52$ with an average contraction of $8.69 \%$. Furthermore, for the condition of Indonesia's export-import against Thailand, where there was an import contraction of $\$ 2,173.41$ or an average contraction of $26.17 \%$. Meanwhile, Indonesia's export-import conditions against India with an export contraction of \$5,195.32 or an average contraction of 15.96\%. Furthermore, the exportimport condition of Indonesia against the US with a contraction value of exports was $\$ 6,355.70$ or an average contraction of $6.15 \%$.
\end{abstract}

Keywords: Export and Import

\section{Introductiom}

International trade can be interpreted as trade transactions between one country's economic subjects and another country's economic subjects, both regarding goods and services. Sobri (2001). Meanwhile, according to Mankiw (2013) states that trade between countries in the world based on comparative advantage means that trade can be profitable because it makes each countryspeculate. Trading will only occur if no one party gets a profit and there is no loss from the other party or it is called gains from trade. Basically, international tradeis an activity that involves the supply (export) and demand (import) between countries. At the time of exporting the country receives foreign exchange for payment and this foreign exchange will be used to finance imports

According to Porter (2008) The Competitive Advantage of Nation isabout the absence of a direct correlation between two production factors (high natural resources and cheap human resources) owned by a country to be used as competitiveness in trade. In contrast, according to Nopirin (1999) in international trade, there is a need for policies as government economic actions or policies that directly or indirectly affect the composition, direction and form of international trade. The instrument of international trade policy is through government action on the current account of the international balance of payments, particularly regarding exports and imports of goods or services such as the imposition of import tariffs and bilateral trade agreements. In Salvatore's view, (2014) that the use of resources in trading activities in the two countries can be used by determining the most efficient production value. Hady (2001) argues that through international trade in exports it will increase foreign exchange reserves through foreign exchange owned by the governmentand private sector of a country. Meanwhile in Fitriani's research (2019) that to increase the value of Indonesian exports, product diversification must be carried out and increase product competitiveness. It is different according to Wulandari's research (2019) which reveals the importance of investing in international tradeso that it affects economic growth.International trade is carried out by residents of a country with residents of other countries on the basis of mutual agreements. The population in question can be between individuals or individuals and individualsas well as between individuals and the government of a country or the governmentof a country and the government of another country. Lestari (2011). Meanwhile, according to Sukirno (2009) explained that there are eight factors that encourage international trade, namely to meet domestic needs for goods and services and the desire to gain profits and increase state income. (Boediono, 1999)

A different view according to Parkin (2017) that in international trade, therelationship between the quantity of goods demanded and the price is in the law ofdemand. The law of demand states that when other things remain the same, the higher the quantity demanded and the lower the price of a good the greater the quantity demanded. In contrast, according to Purnamawati (2013) import is one component of expenditure or consumption for goods or services from abroad. In the theory of consumption, it is stated that consumption is determined by the level of income. Likewise, for the consumption of goods and services from abroad, the amount willbe largely determined by the factor of income even though imports are also determined by other factors. Several factors that can affect imports include the level of income, the relative price of goods domestically and abroad, and the domestic exchange rate against foreign currencies. Meanwhile, according to Amir(2007) the activities of exporters and importers of goods or services are different in different countries and make a written agreement in a sale and purchase contract in which it is clearly 
defined regarding the rights and responsibilities of each so as to avoid the possibility of misinterpretation. In its development in general, export-import activities in Indonesia have shown their existence in international trade. Various constraints and problems thatoccur, especially in the process of increasing production. Therefore the need for support and policies to overcome it. On the other hand, a study is needed to determine the position of the condition of Indonesia's export-import activities. So that specifically according to the phenomenon from the previous study and available data, it is necessary to carry out further studies on problems such as how the contraction of exports and imports for the State of Indonesia, China, Japan, Malaysia, Singapore, Thailand, India and the United State (US).

\section{Method}

The types of data used in this study are secondary data with resourcesthrough the publication of the ADB 2020 key indicator. to analyze the growth and contraction of Indonesia's export-importagainst destination countries, use the following formulation

Model for calculating growth in export value:

$\mathrm{Ge}=\frac{\text { Ext }- \text { Ext }-1}{\text { Ext }} \times 100 \%$

A model for calculating the growth in import value:

$G m=\frac{\mathrm{mt}-\mathrm{mt}-1}{\text { Ext }} \times 100 \%$

Model for calculating the contraction value:

Kont $=P_{1}-P_{2}$ atau $P_{2}-P_{1}$

Kont $=\sum P_{1}-\sum P_{2}$ atau $\sum P_{2}-\sum P_{1}$

Kont $=\sum \bar{P}_{1}-\sum \bar{P}_{2}$ atau $\sum \bar{P}_{2}-\sum \bar{P}_{1}$

\section{Results}

Contraction of Indonesia's Exports and Imports against China

The results of calculations for the conditions of Indonesia's export-import trade against China experienced a sharp contraction, evidenced during the last 20 years 2000-2019 with an average contraction of $\$ 5,649.13$ or an average growth of $0.26 \%$. This condition is very worrying and even from 2008-2019, Indonesia's export trade conditions experienced a negative trend, while for China's imports to Indonesia there was even a positive growth, namely an average of $18.64 \%$ or a contraction compared to Indonesia, which was $4,59 \%$. This condition will undoubtedly affect Indonesia's foreign exchange reserves in the international tradebalance and even make Indonesia one of the largest importer countries of productsmade in China. Another view of this condition is that it has an impact on the sovereignty of domestic products and it will even have implications for various economic and psychological sectors in Indonesia. Then, to see the picture of the fluctuation of Indonesia's export-import contraction against China is as follows:

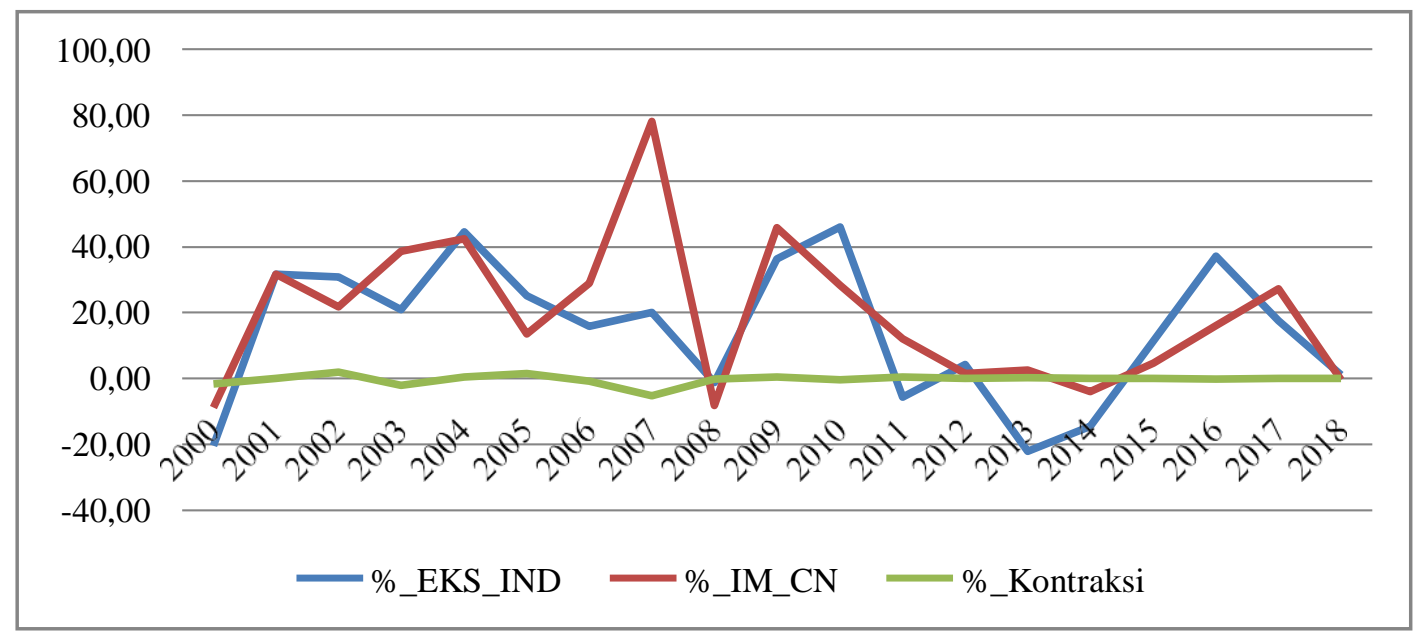

Source: Image data processed

\section{Ficture 1}

\section{Indonesian And China Export-Import Contractions}

\section{Contraction of Indonesian Exports and Imports against Japan}

Meanwhile, the calculation results for Indonesia's export-import activities against Japan are that Indonesia is superior to Japanese imports and even Japan experiences an average import contraction of $\$ 8,387.62$ or $5.31 \%$. This is in line with the total value of Indonesia's exports for the last 20 years, namely from 2000- 2019 an average of 
$\$ 20,287.83$ while the value of Japanese imports to Indonesia was lower, namely $\$ 11,900.21$. This condition makes Indonesia an exporter country for Japan which will have implications for the value of the trade balance and the nation's economy. Broadly speaking, this condition needs to be maintained so that it will increase State revenue through revenue from divisions. To see the fluctuation in the export-import contraction of Indonesia and Japan, itis seen in the following picture:

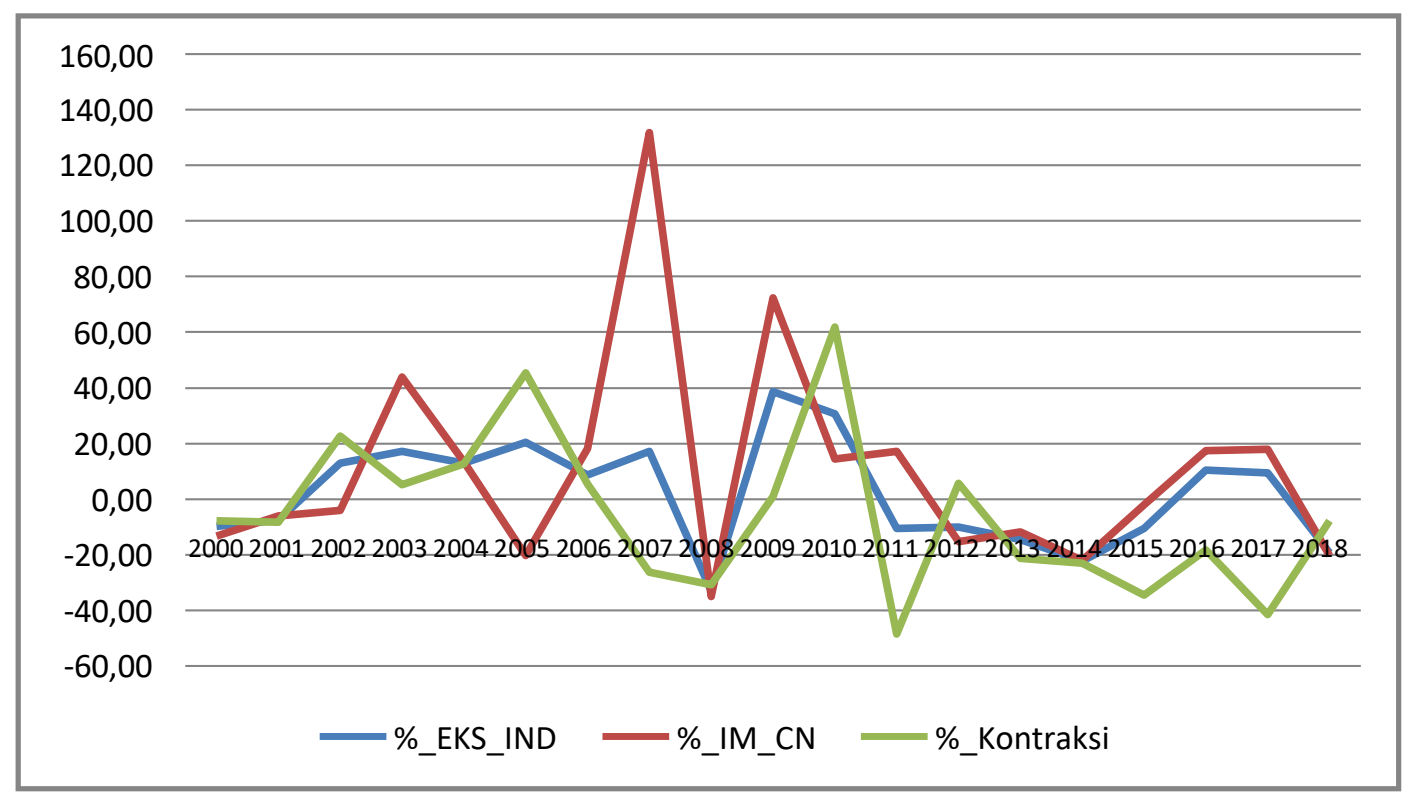

Source: Image data processed

\section{Ficture 2}

Indonesian And Japan Import Export Contractions

\section{Contraction of Indonesian Exports and Imports against Malaysia}

Then the calculation results for the condition of Indonesia's export-import against Malaysia, where during the last 20 years from 2000-2019 the value of Indonesia's exports to Malaysia was actually lower by \$6,099.57 while the value of Malaysian imports for Indonesia was higher, namely amounting to $\$ 6,391.08$ or contracted an average of \$291.51. The other side of this condition illustrates that Indonesia still has a dependence on products made in Malaysia. Furthermore, to see fluctuations in the export-import activities of Indonesia and Malaysia, it canbe described as follows:

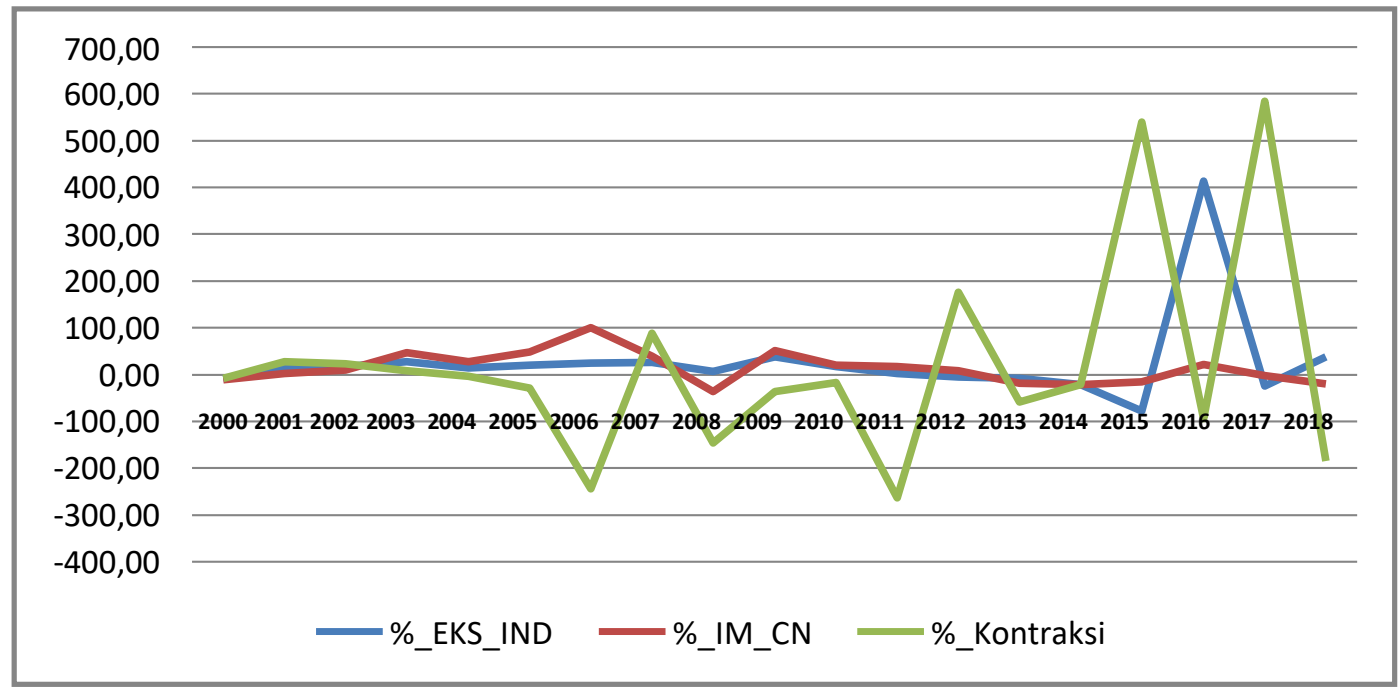

Source: Image data processed

Ficture 3

Indonesia And Malaysia Import Export Contractions

Contraction of Indonesia's Exports and Imports against Singapore

The thing that is far different for Indonesia's exports and imports to Singapore is that it is a country that has 
minimal ownership of natural resources but has a big role in international trade, especially towards Indonesia. This condition makes an afterthought as the Indonesian nation to get out of the economic pressures that occur. This condition can be illustrated that Indonesia's export-import to Singapore during the last 20 years, namely 2000-2019, was proven to have contracted by 3,489.52 $\$$ from the import value of $\$ 14,095.89$ or an average contraction of $8.69 \%$. Meanwhile, Indonesia's export value to Singapore was only $\$ 11,272.88$ or $4.91 \%$. To see the fluctuation of Indonesia's export-import contraction against Singapore, it can be described as follows:

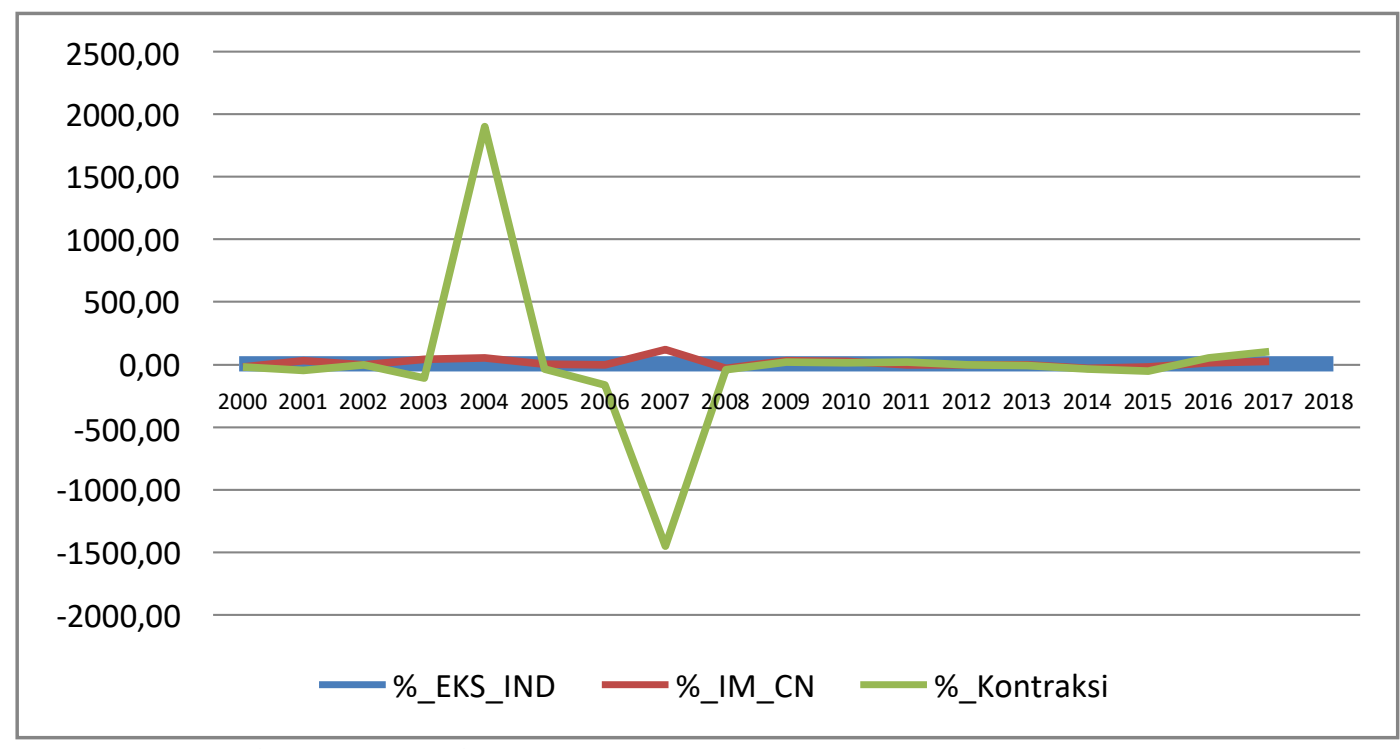

Source: Image data processed

Ficture 4

Indonesia And Singapore Import Export Contractions

\section{Contraction of Indonesian Exports and Imports against Thailand}

Then for the condition of Indonesia's export-import against Thailand, where during the last 20 years from 2000-2019 it shows the low performance of Indonesia's international trade in the global arena, it is evident from the fact that Thailand's import value is actually greater against Indonesia or there has been a contraction of the Indonesian economy of $\$ 2,173.41$ or $26.17 \%$ with Thailand's import value of $\$ 6,221.51$ or a growth of $13.84 \%$. Meanwhile, Indonesia's export value was only $\$ 4,048.10$ or grew by $10.42 \%$. Of course, this condition is the thought of the Indonesian people to get out of the economic dynamics that are happening. On the other hand, this condition will undoubtedly have an impact on the Indonesian economy, especially on the international trade balance traffic through the foreign exchange report. The low performance of Indonesia's international trade will trigger a deficit in the State budget and directly affect the welfare of the Indonesian people. To see the fluctuation in the condition of Indonesia's export-import contraction against Thailand, it can be described as follows:

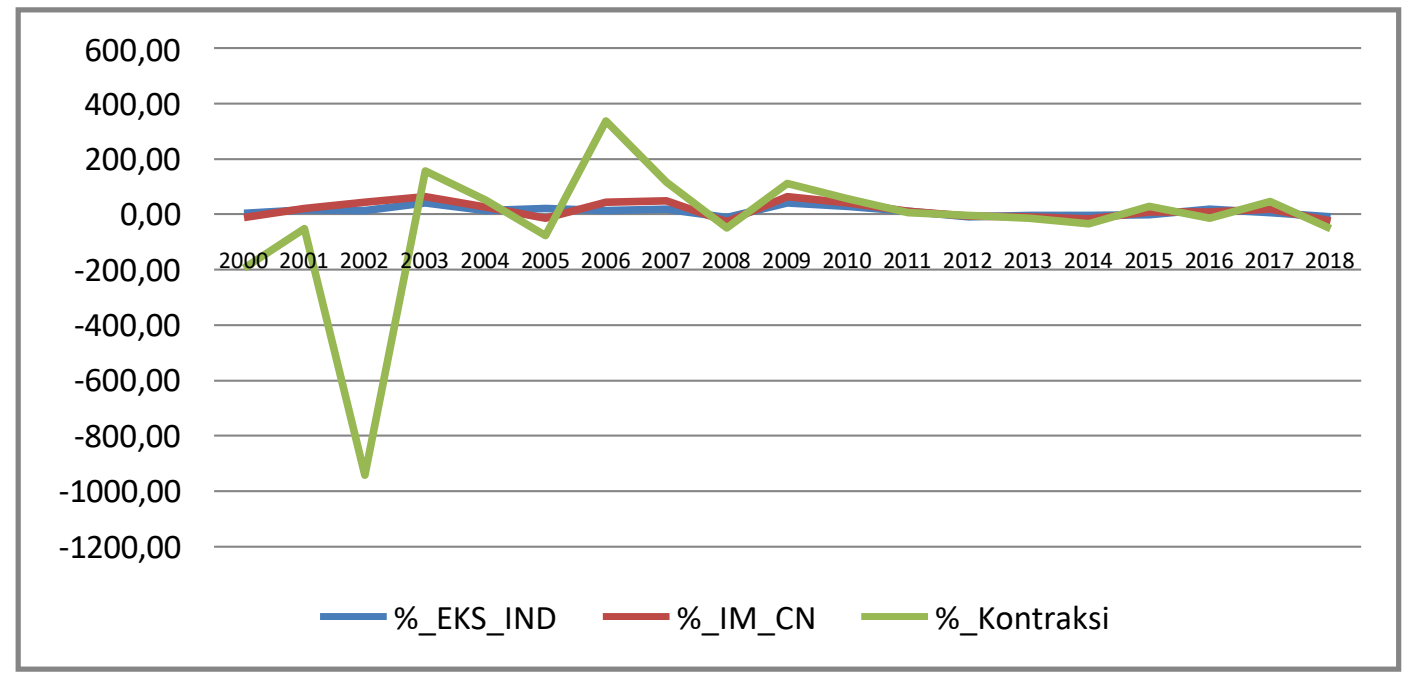

Source: Image data processed in 2021 


\section{Contraction of Indonesian Exports and Imports to India}

Calculation data for Indonesia's export-import conditions against India, where Indonesia has an important role in the trading activities of the two countries. This is evidenced by the fact that Indonesia's export value is greater than India's, amounting to $\$ 7,761.21$ or an average growth of $13.98 \%$. Meanwhile, the condition of India's imports to Indonesia during the last 20 years from 2000-2019 was an average of $\$ 2,505.88$ or grew by $14.42 \%$ faster than Indonesia at $0.44 \%$. On the other hand, India's import conditions against Indonesia experienced a contraction of $\$ 5,195.32$ or an average contraction of $15.96 \%$. The thing that is different and proud of in international trade activities for Indonesia against India when compared to several Asian countries, especially in this study, is that Indonesia has an influence on trade that has been carried out and will have implications for the nation's and state's economy. To see the fluctuation in the condition of Indonesia's export-import contraction against India, it can be described as follows:

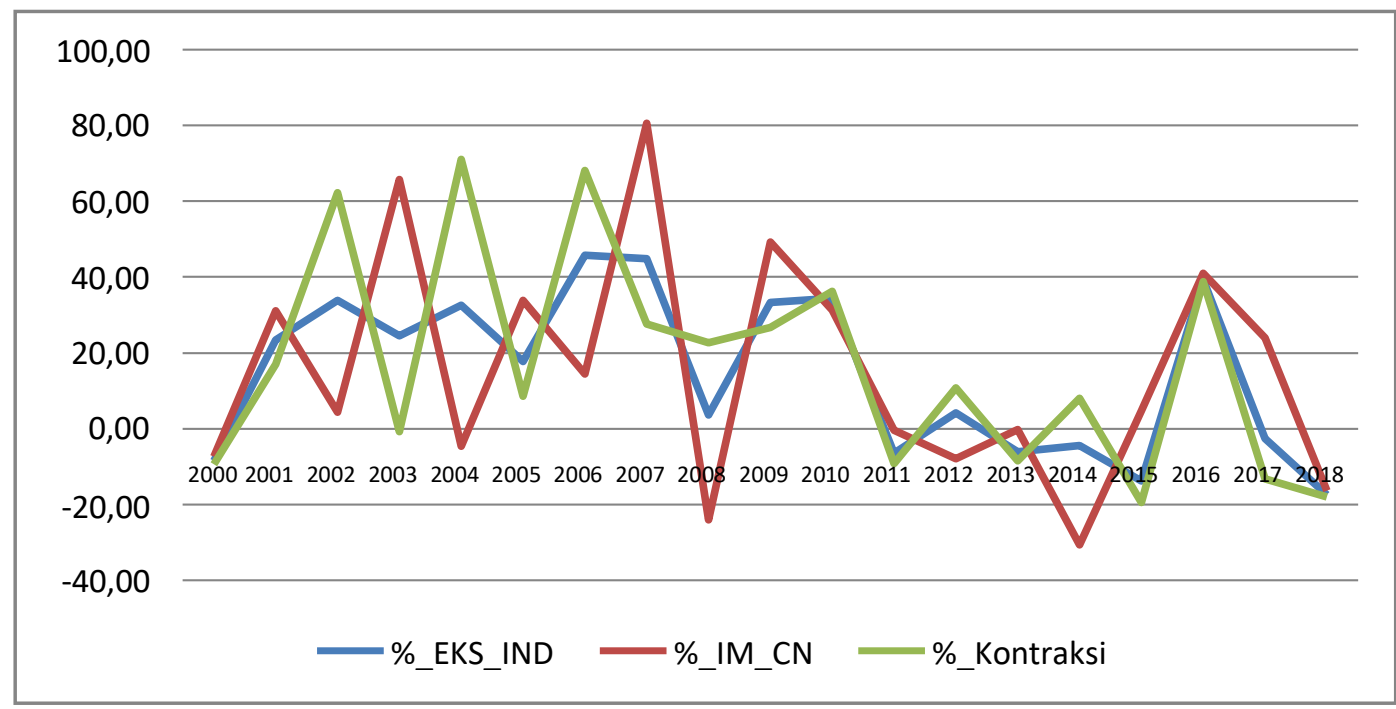

Source: Image data processed in 2021

\section{Ficture.6}

\section{Indonesia And India Import Export Contractions}

\section{Contraction of Indonesian Exports and Imports against the US}

Then for the export-import conditions of Indonesia against the US where for the last 20 years or from 2000 2019, where Indonesia was an exporter country to the US, with a value of $\$ 13,047.63$ or an average growth of $4.24 \%$. Meanwhile, the import activities for the US had a value of $\$ 6,691.93$ or grew by an average of $6.41 \%$. This makes the US a country with a contraction of imports against Indonesia of $\$ 6,355.70$ or an average growth of $6.15 \%$. This is different for the condition of the growth rate of Indonesian exports to US imports, where the tendency of US imports to experience a greater growth of $2.17 \%$ compared to the growth rate of Indonesian exports. The conditions of Indonesia's trade against the US can be described as follows:

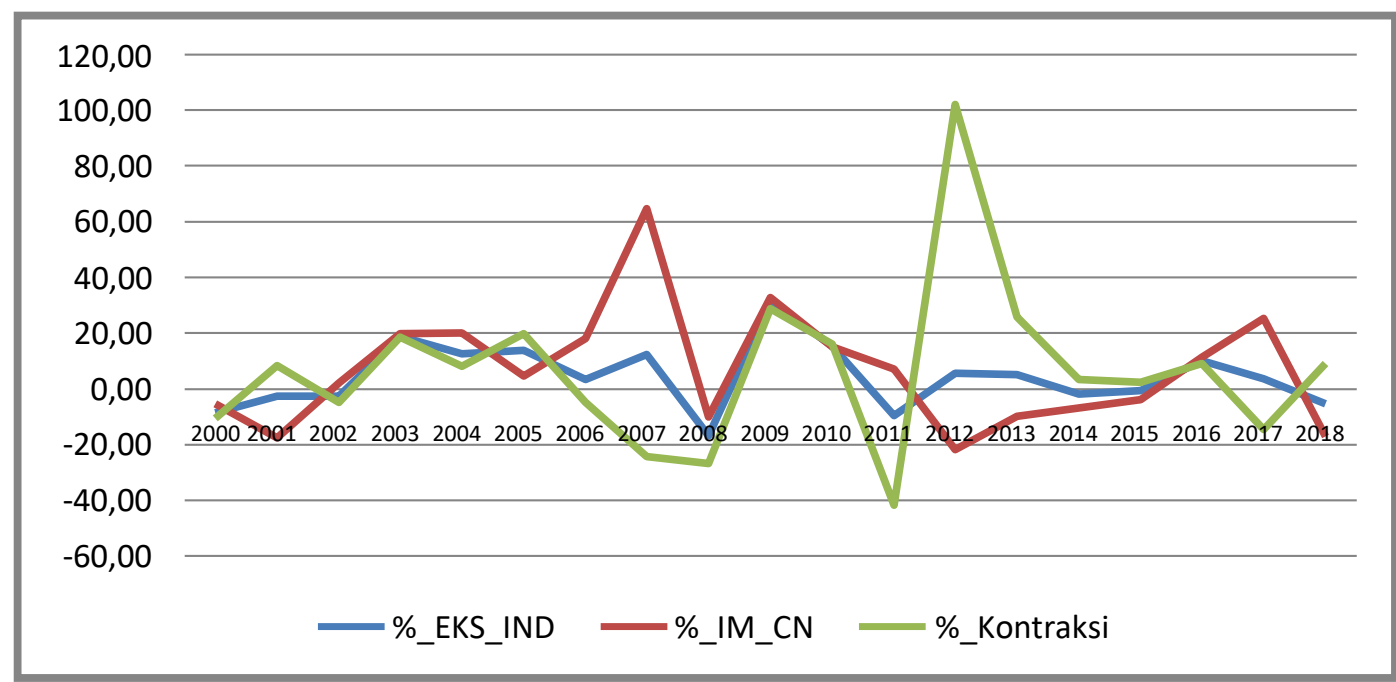

Source: Image data processed in 2021

Ficture.7. Indonesia And Us Import Export Contractions 


\section{Conclusion}

Through the calculation model of growth and contraction for the conditions of Indonesia's export-import trade against China, which experienced a sharp contraction during the last 20 years 2000-2019 a negative average of $\$ 5,649.13$ or an average contraction of $0.26 \%$. Meanwhile, the condition of China's imports to Indonesia grew positively by an average of $18.64 \%$ or a contraction of $4.59 \%$. Then for the condition of Indonesia's export-import against Japan, Indonesia is actually superior and the contraction of Japanese imports is by an average of $\$ 8,387.62$ or by growing with a contraction of $5.31 \%$. Meanwhile, the total value of Indonesia's exports during the last 20 years was an average of $\$ 20,287.83$ and the value of Japanese imports to Indonesia was lower at $\$ 11,900.21$. Furthermore, for the condition of Indonesia's export-import against Malaysia, where during the last 20 years the value of Indonesia's exports to Malaysia was actually lower at $\$ 6,099.57$, while for Malaysia's import value against Indonesia was higher, namely amounting to $\$ 6,391.08$ or experienced an average contraction. for $\$ 291.51$.

Then for exports and imports of Indonesia to Singapore, it is precisely a country that has minimal ownership of natural resources but has a big role in international trade, especially towards Indonesia. Where the export-import condition of Indonesia against Singapore for 20 years is proven to have contractedby $\$ 3,489.52$ with an import value of $\$ 14,095.89$ or an average contraction of $8.69 \%$. Meanwhile, Indonesia's export value to Singapore was only $\$ 11,272.88$ or grew by an average of $4.91 \%$. Furthermore, for the condition of Indonesia's export-import against Thailand, it shows the low performance of Indonesia's international trade in the global arena as evidenced by the fact that Thailand's import value is actually greater against Indonesia or there is a contraction in the Indonesian economy of $\$ 2,173.41$ or a contraction of $26.17 \%$ with Thailand's import value. amounted to $\$ 6,221.51$ or grew by an average of $13.84 \%$. Meanwhile, Indonesia's export value was only $\$ 4,048.10$ or grew by an average of $10.42 \%$.

Meanwhile, Indonesia's export-import conditions against India, where Indonesia plays an important role in the trading activities of the two countries, with Indonesia's export value being even greater than India's, amounting to $\$ 7,761.21$ or an average growth of $13.98 \%$. Meanwhile, the condition of India's imports to Indonesia reached an average of $\$ 2,505.88$ or grew by an average of $14.42 \%$ faster than Indonesia's $0.44 \%$. On the other hand, the condition of India's imports to Indonesia experienced a contraction of $\$ 5,195.32$ or an average contraction of $15.96 \%$. Furthermore, for the export-import condition of Indonesia against the US, where Indonesia is an exporter country to the US, with a value of $\$ 13,047.63$ or an average growth of $4.24 \%$. Meanwhile, the import activities for the US had a value of $\$ 6,691.93$ or grew by an average of $6.41 \%$. This makes the US a country with a contraction of imports against Indonesia of $\$ 6,355.70$ or an average growth of $6.15 \%$. This is different for the condition of the growth rate of Indonesian exports to US imports with the tendency of US imports to experience agreater growth of $2.17 \%$ compared to the growth rate of Indonesian exports.

\section{Reference}

Amir M.S, 2007. Export and Import: Theory and Application. PPM. Jakarta

Astuti Purnamawati, 2013. Basics of Export Import. Sinar Grafindo. Yogyakrta

Boediono, 1999. Economic Growth Theory. BPFE. Jakarta.

Dominick Salvatore, 2014. Trade and Payments in Central and Eastern Europe's Transforming Economies.

Efi Fitriani, 2019. Analysis of the Influence of International Trade on Indonesia's Economic Growth. Journal. 9(1)

Hady, Hamdy. 2001. International Economics: International Financial Theory and Policy. Erlangga. Jakarta

Laili Monita Wulandari and Saifudin Zuhri, 2019. The Influence of International Trade and Investment on Indonesia's Economic Growth in 2007-2017. Journal of Rep, 4(2)

Mankiw, N. G, 2013. Introduction to Macroeconomics.Salemba Publisher. Jakarta Michael E.

Porter. 2008. Competitive Advantage. Twelfth Edition. Third Print. PT. Index. Jakarta

Nopirin, 1999. International Economics. 3rd Edition. FEB UGM. Yogyakarta.

Parkin, Michael, 2017. Microeconomics. Four Salemba. Jakarta

Setiawan, Heri Lestari and Sari, 2011. International Trade. Pustaka Nusantara. Yogyakarta

Sukirno Sadono, 2009. Introductory Micro Economics Theory Third Edition. PT.Gramedia Pustaka Utama. Jakarta

Sobri, 2001. International Economics: Theory of Problems and Wisdom. BPFE-UI. Yogyakarta 